\title{
Examining Undergraduate Students' and In-Service Graduates' Perceptions of Their Professionally Oriented Foreign Language Needs
}

\author{
Olga Marina \\ National Research University Higher School of Economics
}

\begin{abstract}
Correspondence concerning this review article should be addressed to Olga Marina, School of Foreign Languages, Department of Foreign Languages, National Research University Higher School of Economics, Bolshaya Ordynka 47/7, Moscow, Russian Federation, 115184. E-mail: marinaolga2010@gmail.com
\end{abstract}

Irina Yakusheva

National Research University Higher School of Economics

\begin{abstract}
Correspondence concerning this review article should be addressed to Irina Yakusheva, School of Foreign Languages, Department of Foreign Languages, National Research University Higher School of Economics, Bolshaya Ordynka 47/7, Moscow, Russian Federation, 115184.E-mail: iyakusheva@hse.ru
\end{abstract}

\author{
Oksana Demchenkova \\ National Research University Higher School of Economics
}

\begin{abstract}
Correspondence concerning this review article should be addressed to Oksana Demchenkova, School of Foreign Languages, Department of Foreign Languages, National Research University Higher School of Economics, Bolshaya Ordynka 47/7, Moscow, Russian Federation,115184.E-mail:demks@bk.ru
\end{abstract}

\begin{abstract}
Increasing workplace demands on foreign languages skills in professional settings call for a number of considerable changes in the university learning context regarding foreign language teaching. The present study aimed to assess the language needs within and across employed university graduates, first, third, and fourth-year students of non-language majors to further inform such changes. All four language skills, the context of both current foreign language education programs and the use of a foreign language at the workplace were considered. Questionnaires including Likert scale, multiple choice, and open-ended items were distributed among 110 students and 35 currently employed graduates. Descriptive statistics and one-way Analysis of Variance (ANOVA) followed by Tukey HSD and Holm-Bonferroni tests were used to analyze the data. The results indicated several areas of agreement among the participants: A clear need for all four language skills to be developed as high as C2 level and the consistent need to improve speaking. However, several noticeable discrepancies between the perceptions of the target groups regarding the context of workplace language use, such as how often, where, and with whom they expect to communicate, and need for professionally oriented foreign language were revealed. Overall, students may need to be more informed about the challenges regarding the workplace context for language use.
\end{abstract}

Keywords: foreign language curriculum, foreign language teaching, Language for Specific Purposes (LSP), needs analysis, workplace communication

\section{Inrtoduction}

In a globalized workspace, a good command of a foreign language is instrumental for achieving professional goals. The trend is expected to gain momentum, especially for the English language, given that "English continues to 
be the lingua franca in many contexts worldwide" (Serafini, Lake, \& Long, 2015, p.16). The necessity of foreign language skills in addressing the actual needs of future professionals has been widely discussed in numerous research studies on teaching English as a Foreign Language published as individual papers (e.g., Basturkmen \& Wette, 2016, Belcher, 2009; Hyland, 2007; Hyland \& Hamp-Lyons, 2002; Dudley-Evans \& St. John, 1998) as well as collections of articles by various prominent researches united around this topical issue (Kirkgöz \& Kenan Dikilitaş (Eds., 2018).

With the growth of cross-cultural economic and political contacts, having a good command of a foreign language for achieving professional goals is becoming of great practical importance for university graduates in the Russian Federation. The modern Federal State Educational Standards (FSES) for Higher Education in the Russian Federation not only set out learning outcomes and curricula structure for professionally oriented foreign language (LSP) courses $^{1}$, but also allow substantial academic freedom in ensuring curriculums content compliance with labor market requirements. Moreover, the revised FSES for Bachelor programs (2017) further stress the need for curriculums informed by the analysis of professional needs in multicultural professional environments. In view of these changing educational and societal requirements, it becomes obvious that curriculum design for teaching English in Russian universities should be reconsidered, with labor market demands in mind.

However, the process of introducing modified LSP courses into university curriculums has turned out to be a complicated issue. At the moment, the debate in the Russian community among foreign language teachers as to what to teach in LSP is as heated as ever (Kazakova, 2011; Solovova, 2009). The current debate concerns the focus in teaching LSP: general language issues, business vocabulary or mostly professional content, and the proportion of attention that should be paid to the four language skills. The issue lies not only in selecting some of the methodological concepts of teaching English to be implemented in teaching LSP courses, but rather in assessing the teaching context and aligning it with the students' practical needs, the range of which depends on their future professional demands.

Developing models of effective LSP courses that prepare students for their future professional environments has been a challenging task not specific only to the Russian context. US Higher education institutions offering LSPs have been monitoring the curricular options since 1990, noting that the courses are striving to become "more focused in response to broader needs" (Long \& Uscinski, 2012, p.173). At the same time, challenges of implementing LSP programs (Lear, 2012) and raising students' awareness of their goals as a factor of success (Stevens, 2017) have been noted.

The tasks are equally relevant for the School of World Economy and International Affairs of the National Research University Higher School of Economics (NRU HSE). Students of NRU HSE study two foreign languages; they have an option of choosing one out of eight world languages (German, Italian, French, Spanish, Portuguese, Japanese, Chinese, or Arabic), with English being the mandatory foreign language for every student. However, limitations on institutional language learning organization, such as the recent cut in the number of foreign language class hours by one third in the four recent years, as well as the rapidly changing landscape in the working environment, pose challenges that should be addressed effectively and in a timely manner to meet the students' needs.

The present research aims to compare the perceived language needs of LSP first, third, and fourth-year students at the School of World Economy and International Affairs (NRU HSE) and the perceived language needs of the employed graduates in order to determine the effectiveness of the learning context in developing the expectations and perceived language needs of LSP students in relation to their future professional requirements. To this end, the following research questions guided this study:

1. What are LSP students' perceived foreign language needs with regard to their future professional contexts?

2. What are employed graduates' perceptions of their current language needs in their professional context?

3. How do the LSP students' and in-service graduates' perceptions of their language needs differ?

\footnotetext{
${ }^{1}$ The Federal State Educational Standards in the Russian Federation for Bachelor programs. (2017). Retrieved from http://fgosvo.ru/fgosvo/92/91/4
} 


\section{Literature Review}

The needs analysis has become a necessary part of curriculum development in general foreign language teaching (Brown, 2001; Hutchinson \& Waters, 2002; Nunan \& Lamb, 1996; Yalden, 2000) and later English for specific/academic purposes (ESP/EAP) (Basturkmen \& Wette, 2016) to define the courses' goals and objectives. Currently, a needs analysis is a feature that provides "one of the strongest links between EAP and ESP" (Hyland \& Hamp-Lyons, 2002, p.5). Although the authors' research deals with teaching various foreign languages (LSP) rather than only English for specific purposes, the background of the research in ESP is used as the theoretical ground for the present paper for a few reasons. ESP seems to be more widely explored, it informs LSP, and it is mostly cited (Lafford, 2012). The terms LSP/ESP are used intermittently in some studies to discuss common grounds and shared issues (Howard \& Brown, 1997).

Recent studies define the current experience in LSP/ESP as increasingly difficult to summarize or present, describing it as "a single stop-action frame" (Belcher, 2006, p.135), and give the current view of the ESP context as "dynamic, continually changing" (Douglas, 2000), socially constructed by multiple stakeholders rather than only learners (Canagarajah, 2002). A number of studies have focused on different stakeholders' needs-related concepts. Among them are numerous studies on the workplace requirements for foreign languages use (Ching Hei, David, \& Su Kia, 2013; Crosling \& Ward, 2002; Kassim \& Ali, 2010; Nur, 2011; Spence \& Liu, 2013; Talib, 2018) that overwhelmingly state the need for improvement in teaching relevant professional communication skills to be implemented in various industries. The role of "work-related factors" (Shooshtari, 2018, 193) in higher ESP education is often considered important for students to see "a practical applicability" in what students learn (Marza, 2012). Research on the perceived needs of ESP learners focuses on developing methodological approaches both to alleviate the problems of students first entering an ESP course (Evans \& Morrison, 2011; Marza, 2012) and to customize curricula design to enhance graduates' employability (Kavaliauskien \& Uzpaliene, 2003; Kazar \& Mede, 2015; Liu, Chang, Yang, \& Sun, 2011; Tan, Teoh, \& Tan, 2016; Varghese, 2012). There is a body of research that compares the perceived needs of ESP learners to those of the instructors (Zohren, 2010), the ESP-learning context versus learners' future discourse community needs (Garcia, 2002), business communication versus reality (Louhiala-Salminen, 1996), as well as multiple stakeholders' views (Taillefer, 2007) in recognition of the impact that the subjective needs that learners have on the learning process in ESP contexts (Tudor, 1977).

Similar studies by Russian researchers in the field of LSP/ESP in the analogue contexts of Russian universities mostly outline the LSP/ESP aims and syllabi of professionally oriented courses. For instance, Komarova and Oks (2016) give a comprehensive description of the structure and content of a specialized ESP course in tourism at Lomonosov Moscow State University; Orlyanskaya (2012) outlines a syllabus for introducing future FL teachers to major issues of teaching LSP/ESP. Although both of the papers contain valuable insights into the principles of LSP/ESP courses design, they do not provide any empirical data for their conclusions. The study by Sarsenbayeva and Kulakhmetova (2015) employs a needs assessment in order to design an ESP course for students in thermal engineering. It offers a discussion of the target situation, present situation, and context analysis based on the data that was collected through questionnaires, observations, and interviews of students and instructors at Kemerovo State University. Still, the focus is on the recommendations for a particular course while the research procedure, the empirical data, and the data analysis stay outside the framework of the article.

The existing studies present a clear picture of the learning and target needs in various professional areas and their interrelations; however, they still give rise to some points of interest. First, all of them give the stop-action frame of the learning needs, thus questions arise regarding the dynamics shaping those needs and interrelations. Also, reformulating the question "Is what I need what I want?" (Liu et al., 2011, p. 271), there may be a need to answer to the question if students want to learn about what they really need.

The present research builds on the insights that are drawn from previous studies in an attempt to assess the needs of LSP students at the School of World Economy and International Affairs (NRU HSE). Similar to the studies mentioned above, the present research follows Hutchinson and Waters (1987) in investigating the three categories of needs in terms of necessities, lacks, and wants. The three components of the needs (Hutchinson \& Waters, 1987, p. 54) regard the target situation as their focal point either as the estimation of its communicative demands (for necessities), or gaps between the existing proficiency and the proficiency requirements of the target situation (for lacks), or learners' perceptions about their needs in the target situation (for wants). For the 
present research, the learning needs as perceived by LSP students of NRU HSE are compared with the perceptions of LSP needs provided by employed graduates of the university. Thus, for LSP students, the needs are defined by their perceptions of a possible future target situation, while the graduates assess their needs against the reallife workplace communication context. To follow Dudley-Evans and St. John (1998), the study's focus was on investigating the specific needs of learners regarding language skills, discourse, and genres appropriate to their future professional activities to inform the choice of the underlying methodology and activities in the context of the relevant discipline.

\section{Materials and Methods}

\section{Participants}

The participants in this study were 110 non-linguistic major LSP students of the School of World Economy and International Affairs (NRU HSE): 40 first-year students, 31 students from the third year, and 39 students in their fourth year of study in the spring term of 2015. Responses were also collected from 35 graduates of the School of World Economy and International Affairs (NRU HSE) from the years 2007-2012. Female participants slightly outnumbered males in all groups: 23 females (57.5\%) and 17 males (42.5\%) in the first-year group; 18 females (58.1\%) and 13 males (41.9\%) in the third-year group; 22 females (56.4\%) and 17 males (43.6\%) in the fourthyear group; 20 female $(57.1 \%)$ and 15 male $(42.9 \%)$ graduates. The age of the responding students was in the range of 17-23 years with the mean of $17.45,19.41$, and 20.9 for the first, third, and fourth-year student groups respectively. The graduates were in the 28 -30 age group with $16 \%$ of the respondents defining their age as being over 30. Only two participants (graduates) were non-Russian native speakers (Armenian).

The students and graduates involved in the research studied for two majors offered by the NRU HSE School: World Economy (WE) and International Relations (IR). As language classes are mixed groups of the two majors, all responding groups included both students majoring in WE and IR in the proportions of 57.5/42.5\%, 54.9/45.1\% and $48.7 / 51.3 \%$ for the first, third, and fourth-year groups respectively. Among the graduates, $59 \%$ of the respondents majored in WE and $41 \%$ of the responded majored in IR. The inclusion of students at different educational stages expands the scope of the analysis to investigate possible dynamics in the possible divergences of students' needs perceptions according to the stage of students. The students in their first year of studies were particularly chosen to collect the entry stage date for comparison.

\section{Materials}

The questionnaire as the data collection instrument was used to identify the perceptions of language needs within the groups of participants: students and graduates. The students and the graduates were asked about their perceptions regarding any of the two languages they were studying or studied in the university and either expected them to be their main future working language or the most used one for their current work. Therefore, the research covers data collected for German, Italian, French, Spanish, Portuguese, Japanese, Chinese, Arabic, and English languages mentioned in this paper as foreign languages (FLs). The questionnaire items were adopted from the questionnaires in Taillefer's (2007) study ${ }^{2}$ with an adaptation (questions 6, 7, 17) in line with the researcher's suggestion for the questionnaire improvement (Taillefer, 2007, p.14); for this, the QALSPELL questionnaire items were adopted from Thematic Network Project in the Area of Languages III $(2005)^{3}$, a part of the European Commission Leonardo program that is aimed at improving the quality of vocational teaching and training. The QALSPELL questionnaire provides items on the rhetorical context of reading, writing, listening, and speaking for specific purposes.

The six-level CEFR framework (Council of Europe, 2001) ${ }^{4}$ was adopted to assess the students' perceptions of levels of language competence in any language they regarded as most operational in their future or current professional context. The languages in questions are the ones on the students' curriculum or studied by the graduates of School of World Economy and International Affairs at NRU HSE: Arabic, Chinese, English, French,

\footnotetext{
${ }_{2}^{2}$ Permission to use the questionnaire for the publication was obtained from the researcher, Gail Taillefer, on August 23, 2016 via email.

${ }^{3}$ European Commission. (2005). Thematic Network Project in the Area of Languages III. SuProject Two: Languages for enhanced opportunities on the European labour market. Synthesis report. Retrieved from http://eacea.ec.europa.eu

${ }_{4}^{4}$ Council of Europe. (2001). Common European framework of reference for languages: Learning, teaching, assessment. Cambridge, UK: Press Syndicate of the University of Cambridge. Retrieved from http://www.coe.int/t/dg4/linguistic/cadre1_en.asp
} 
German, Italian, Japanese, Portuguese, and Spanish. Although CEFR is perceived as being applied mostly to the English language teaching and testing, the framework has been widely used as the basis for designing such international tests for European languages as the DELF (Diplôme d'Études en Langue Française) diploma or the Goethe-Zertifikat. Moreover, CEFR has been used as a framework to align with for a few non-European language tests such as the 2010 Japanese Language Proficiency Test or JLPT (Bucar, Ryu, Skof \& Sangawa, 2014) and the new standardized Chinese Proficiency Test (HSK) HSK for non-native speakers (Teng, 2017). CEFR is also being implemented in the higher education teaching and learning of Arabic as a second language (Soliman, 2017). Thus, the validity of the questionnaire for the range of languages relies on the cited studies.

The uniformity of the instrument for greater reliability (Mackey \& Gass, 2005), was a particular concern. The two versions of the questionnaire (for students and graduates) were parallel but varied somewhat to include items that were relevant to each of the target groups. The questionnaire consisted of 28 multiple-choice, openended, and Likert scale items for graduates and 25 items for students. Only the graduates were asked about their in-service professional training. Some question items were reworded: for example, future tenses were used in workplace-related questions that were addressed to students, while the present tense was used in question items for the graduates. Table 1 shows the breakdown of the questionnaire items according to their focus. Appendix A presents the graduates' version of the questionnaire.

Table 1

Breakdown of questionnaire items

\begin{tabular}{ll}
\hline \multicolumn{1}{c}{ Eliciting: } & \multicolumn{1}{c}{ Question N } \\
\hline Participants' background & $1-9$ (q-s 8-9 only for graduates) \\
Perceived future or current context of language use for professional purposes & $10-14,17$ \\
Perceived requirements for professional language use & $16,24,25$ \\
Perceived needs in professional language use & 15,22 \\
Perceived level of language competence at the current stage vs. the level required in professional & $18-21$ \\
contexts & \\
Participants' perceptions of their language learning experiences at the university. & $23,26-28$ \\
\hline
\end{tabular}

\section{Procedure}

For the students' questionnaire response groups, a random cluster sampling procedure was employed to choose a group from every major language specialization, which constituted approximately $30 \%$ of the overall number of students per year of study. For the graduates, snowball sampling was employed. Prior to the data collection procedure, the Chair for the Department addressed the students and instructors, and also contacted former students through the alumni network to inform them of the research purpose and its procedure to obtain their consent.

The review of the questionnaire was performed by two department researchers, and the pilot study included one representative from each group of the research population, whose suggestions following their questionnaire response experience were considered. Those reviewers were later excluded from the data collection process.

Pen-and-paper responses were collected simultaneously on one day with the cooperation of the department instructors to prevent sharing information among the responding students. The graduates were reached by distributing an electronic version of the questionnaire through the HSE Alumni Association center. The raw data were transferred into an electronic format and grouped into categories. The SPSS for Windows, version 16.0, was employed for all statistical analyses.

\section{Data Analysis}

Descriptive statistics, such as the percentage, mean, and standard deviation, were used to analyze the demographic information of the participants and their perceived levels of language competence. As the research design required comparisons of more than two groups, one-way Analysis of Variance (ANOVA) was chosen to clarify whether the value of variables differed significantly among the groups. To determine the location of any possible differences, ANOVA was followed by post-hoc Tukey HSD and Holm-Bonferroni tests. 


\section{Results}

\section{Participants' Background}

The analysis presented a foreign language (FL) user profile for the students and graduates. In addition to English as a compulsory foreign language, for enrolling in their classes of the languages of choice the students favored Chinese and Spanish (29\% for each), German and Italian (14\% for each), with French and Portuguese to follow. As for the in-service graduates, our findings revealed that the overwhelming majority of them (60\%) use English as the main foreign language in their professional contexts, followed by Japanese (9\%), Chinese (9\%), and other languages.

The graduates mostly worked in Russia (68.6\%) but roughly one-third (31.4\%) were employed abroad, with only $5.7 \%$ employed in an English-speaking country (the USA). At the time of the survey the graduates were engaged primarily in domestic and international trade (34.3\%), followed by finance (14.3\%), logistics and academia (both 11.4\%), consulting (8.6\%), insurance (5.7\%), IT (5.7\%), and marketing (2.9\%). Most graduates worked as specialists in their respective fields (48.6\%); others worked as managers (22.9\%), administrators (14\%), and in other unspecified positions (17.1\%). Two of the respondents did not report their employment status.

\section{Context of FL Use for Professional Purposes}

The graduates reported (q-s 10-14, 17) that they predominantly use their foreign languages (FLs) in their country of study (Russia $=45 \%$ ), followed by non-native countries for the FLs $(28 \%$ ), and native countries for the FLs (24\%). Only half of the former graduates (52\%) mostly use FLs with native speakers more often than with non-native speakers (42\%). Most of the former graduates need to use direct contact, including telephone contact (28\%), followed by formal contact including meetings and presentations (24\%), informal contact (21\%), and virtual contact (21\%), respectively.

In contrast to responses from graduates, students reported expectations to use foreign languages outside their own country, mostly in the countries where the FLs are the mother tongue (73\% for first year, $82 \%$ for third year, and $65 \%$ for fourth-year students versus $24 \%$ for the graduates). Moreover, the students overestimated the future opportunity of the interactions involving native speakers to a considerable degree (up to $89 \%$ of the students).

When asked to assess the frequency of using the four language skills (reading, listening, writing, and speaking) at their workplace, nearly all of the former graduates reported that they have to read in a foreign language very often (93\%). The texts encountered most frequently were emails (29\%), contracts (14\%), instructions (13\%), and specialized literature (13\%).

Writing was considered the second most regular activity in the workplace by $79 \%$ of the graduates. The graduates often use this skill for writing business letters (81\%), followed by emails (78\%), translation into foreign and native languages equally (41\% each type of activity), as well as writing memoranda (19\%), professional literature reviews (15\%), and reports (11\%), respectively.

In terms of listening, $66 \%$ of the graduates reported their listening skills as being required "very often" or "fairly often" in tasks such as listening to presentations (52\%), explanations of professional issues (48\%), and instructions (37\%), respectively.

Speaking was noted to be required "very often" (59\%) and "fairly often" (19\%), declining slightly in frequency compared to the three other modalities. Approximately half of the speaking situations involve phone conversations (53\%); moreover, approximately $59 \%$ of the graduates described their conversations as mostly asking and answering questions.

Overall, the fourth-year students proved to be most realistic in their assessment of the frequency of using the four language modalities in the workplace. Similar to the graduates' assessment, the use of reading (58\%) was rated as rather frequent by the fourth-year students, preceded only by listening (60\%), while speaking, though marginally, was reported as the second-least used skill for future workplaces (56\%) after writing (33\%). On the other hand, the first and third-year students expected speaking to be the most used skill (80\% and $74 \%$ 
respectively), followed by listening (66\% and 67\%), and writing (40\% and 57\%), with reading being the least expected (40\% and 29\%). Thus, neither group of students expected reading, and especially writing, to be of as much importance as the graduates reported.

All in all, the three groups of students revealed realistic expectations regarding the specificities of the context for the language use for separate skills. Minor deviations were observed between the students' and the graduates' responses concerning speaking. For example, the students expected more active participation at meetings and when making presentations. Moreover, the students' opinions differed from those of the graduates' with regard to how often, where, and with whom they expected to be using their language.

\section{Perceived Requirements for Professional FL Use for Employment}

The graduates perceived the level of their language competence to be of rather low importance for obtaining their first job (q-n 25). Out of the requested language skills, writing (39\%) and speaking (29\%) were more often called upon in the job search process, which is not surprising when taking into account the need for applicants to write resumes and take part in interviews with potential employers (See Figure 1). Interestingly, speaking skills were cited by half of the respondents (55\%) as having contributed to their failure in their first attempt to get hired compared to both writing and reading (both 18\%) and only reading (9\%), respectively (q-n 24$)$.

Unlike the graduates, the students graded all four skills as highly important for their employment success (overall, more than 63\% per skill), with both the third-year students rating speaking first and the fourth-year students expecting to make more use of reading and writing.

Regarding the importance of foreign language skills for professional communication (q-n 16), the majority in all the groups (61\% and higher) ascribed considerable importance to all four skills. Nevertheless, there are some discrepancies in the perceptions of the importance of particular language skills among the four groups of respondents (see Figure 2).

On the one hand, all of the groups of students may have undervalued the importance of reading skills, and the third and fourth-year students considered writing less important than graduates did. On the other hand, all of the students gave priority to listening and speaking skills, which may be valuable, however these were not the primary skills cited by employed graduates.

Thus, only a partial alignment was observed with the graduates' experience at the different stages of employment. Graduates viewed writing and speaking skills as the most necessary skills for obtaining a job, and valued reading over the other skills for further communication at workplace.

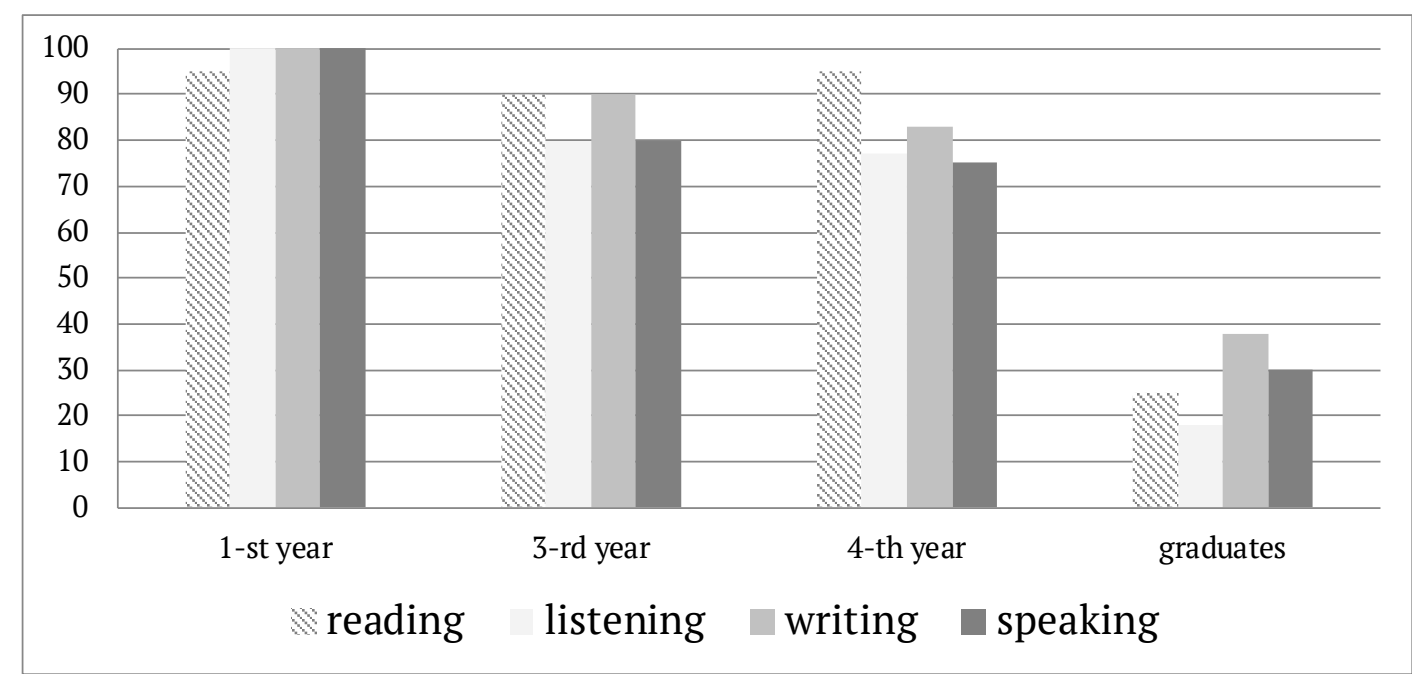

Figure 1. Perceived level of foreign language skills needed for entering the job market (\% of participants).* Note: *All figures report on the percentage of respondents who regarded the skills as "important" instead of "rather important" or "hardly important". 


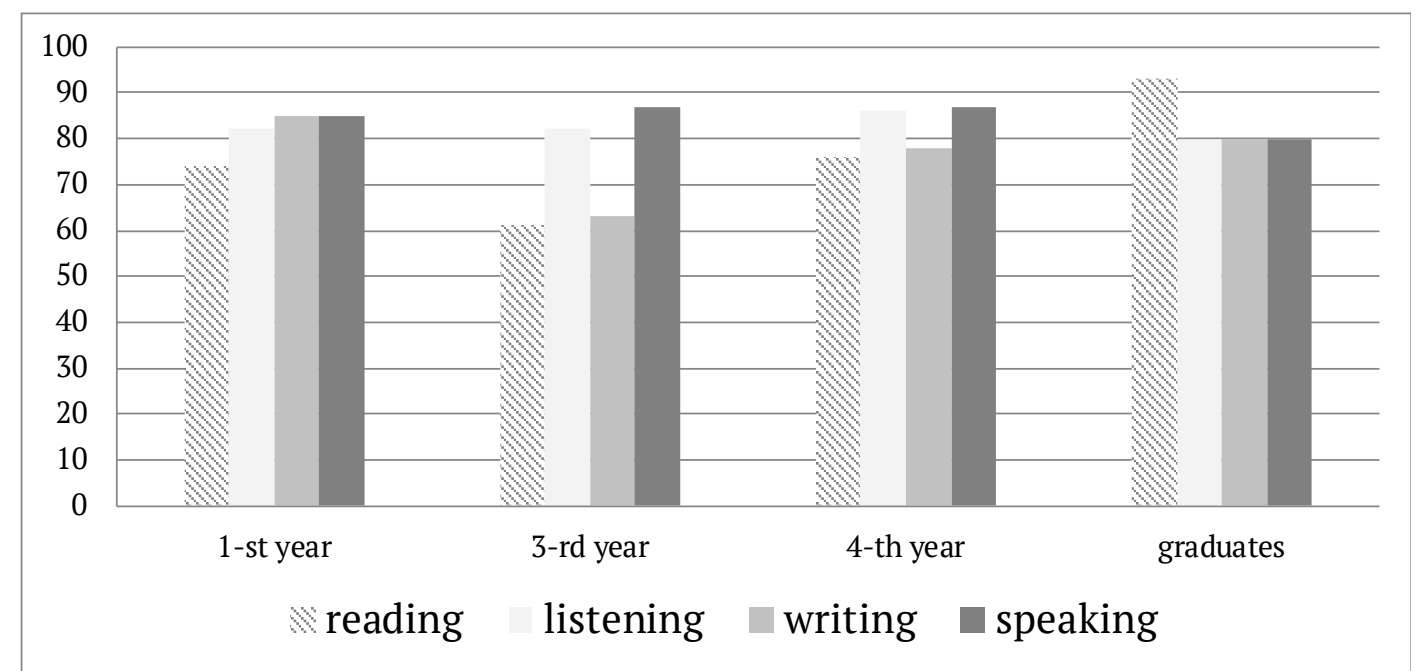

Figure 2. The perceived importance of foreign language skills for professional communication.

\section{Perceived Needs in Professional FL Use}

Although on average $77 \%$ of the graduates assessed their overall foreign language ability as sufficient for entering the job market, they still mentioned oral communications skills as their weakest ones $(\mathrm{q}-\mathrm{s} 15,22)$. Approximately $90 \%$ of the graduates indicated that they felt equally confident about their reading and listening skills, with approximately $80 \%$ of the respondents reporting feeling at ease with writing, while only $60 \%$ of the graduates mentioned that they regard their speaking skills as sufficient. Perception of difficulties in language use and the skills they felt needed the most development for further professional purposes is the area where the most noticeable discrepancies between the graduates and the students were observed.

Figure 3 below echoes our earlier findings on language needs. The results ( $q-n 15)$ show that most of the respondents find reading to be the least problematic skill, with writing rated as the second-least problematic skill. The perception of difficulties in listening and speaking is not as uniform. Listening skills appear to present the biggest difficulties for the first and the third-year students whereas the fourth-year students perceive speaking as their weakest skill. For the graduates speaking and listening skills present equal difficulty. Interestingly, the fourth-year students underestimate the challenges they may face at their workplace regarding reading skills.

The responses of the graduates to the question regarding the necessity to improve particular language skills ( $\mathrm{q}-\mathrm{n}$ 22) reveal a similar pattern. Most of the former graduates think that it is necessary to improve speaking

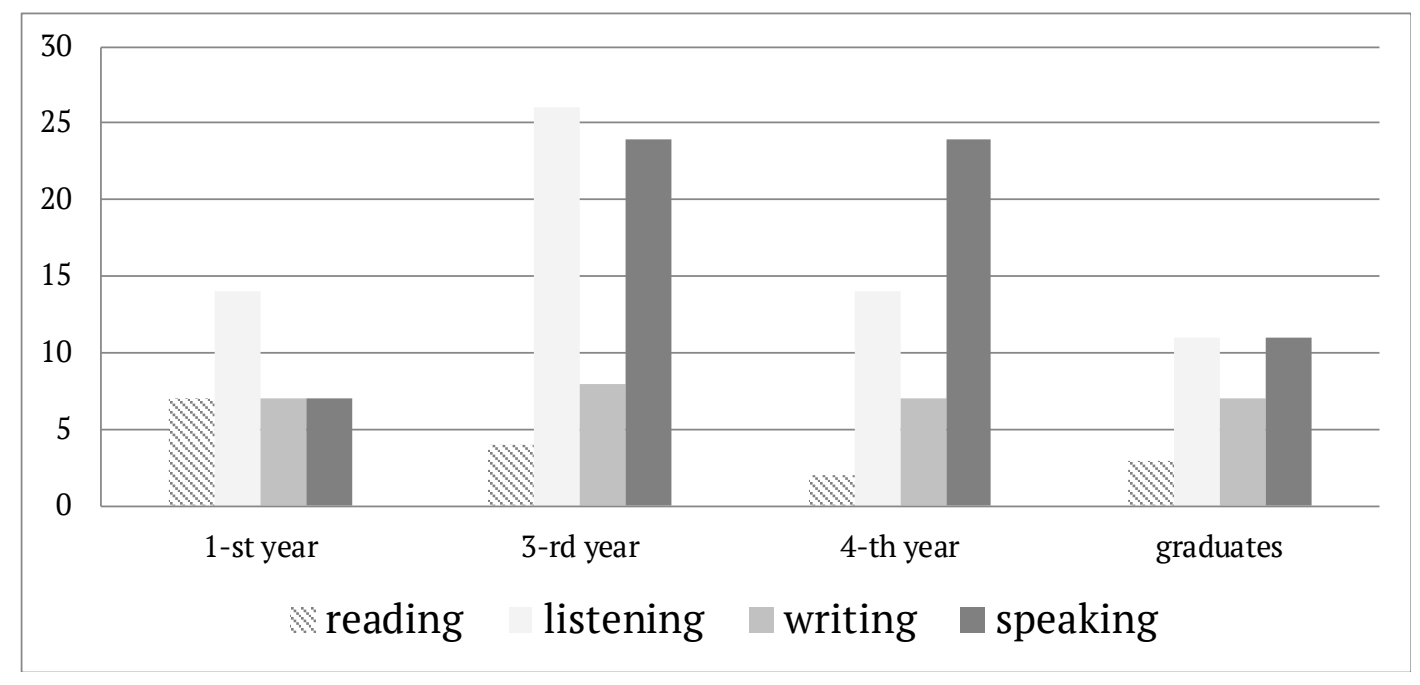

Figure 3. Reported difficulties in using specific language skills. 
skills (38\%), followed by listening (34\%), and writing skills (31\%), respectively (see Figure 4 below). Reading skills were reported to be the least in need of improvement (21\%). The data appear to support the previous conclusions drawn for the graduates; speaking is one of the most required but least developed skills for employment purposes. Still, reading skills, which the graduates reported as being the most needed, were also reported as least needing improvement.

The perception of speaking as the skill which requires the most improvement is shared by the first and fourthyear students. Overall, the fourth-year students were the most realistic in prioritizing their goals on skills development.

In sum, the results in this section appear consistent in indicating that students felt they needed to improve their speaking skills, the need supported by the graduates' responses. Nevertheless, our analysis revealed a gap between the perceived target needs for professionally oriented foreign language use as reported by the graduates and those by the students.

\section{Graduates' and Students' Perceived Levels of FL Competence to Meet Professional Demands}

In assessing their own levels of language competence against the six-level CEFR framework (q-s 18-21), both the graduates and the students expressed a clear need for all four language skills to be developed as high as the C2 level (see Appendix 2). A special focus was on speaking needs as $62 \%$ of the graduates and students reported a need for C2-level skills, which surpassed their current competence. The collective percentages of C1 to C2 levels accounted for $82-93 \%$ of the sample. A closer look reveals a number of differences in the students' perceptions of their needs in language competence development from those of the graduates.

Most graduates indicated that they were quite satisfied with the overall level of their language development regarding reading skills. Nevertheless, they reported a slight need for improvement at the proficiency level (C2) of reading skills. The first-year students report a need for improvement from every level of competence and a complete lack of C2 skills, which they deemed to be required. The third and fourth-year students appeared to formulate their needs in reading with a focus on more complex and advanced skills (C2) than the workplace reality required according to the graduates. At the same time, the students greatly underestimated their ability to use these skills ( $35 \%$ and $12 \%$, respectively, against $65 \%$ for graduates).

The data are supported by a descriptive statistical analysis (see Table 2) showing the means for the groups of respondents.

Both the third and fourth-year students agreed on being generally satisfied with what they could do in writing to meet their needs, while the first-year students reported an expressive need for improvement. Still, the graduates

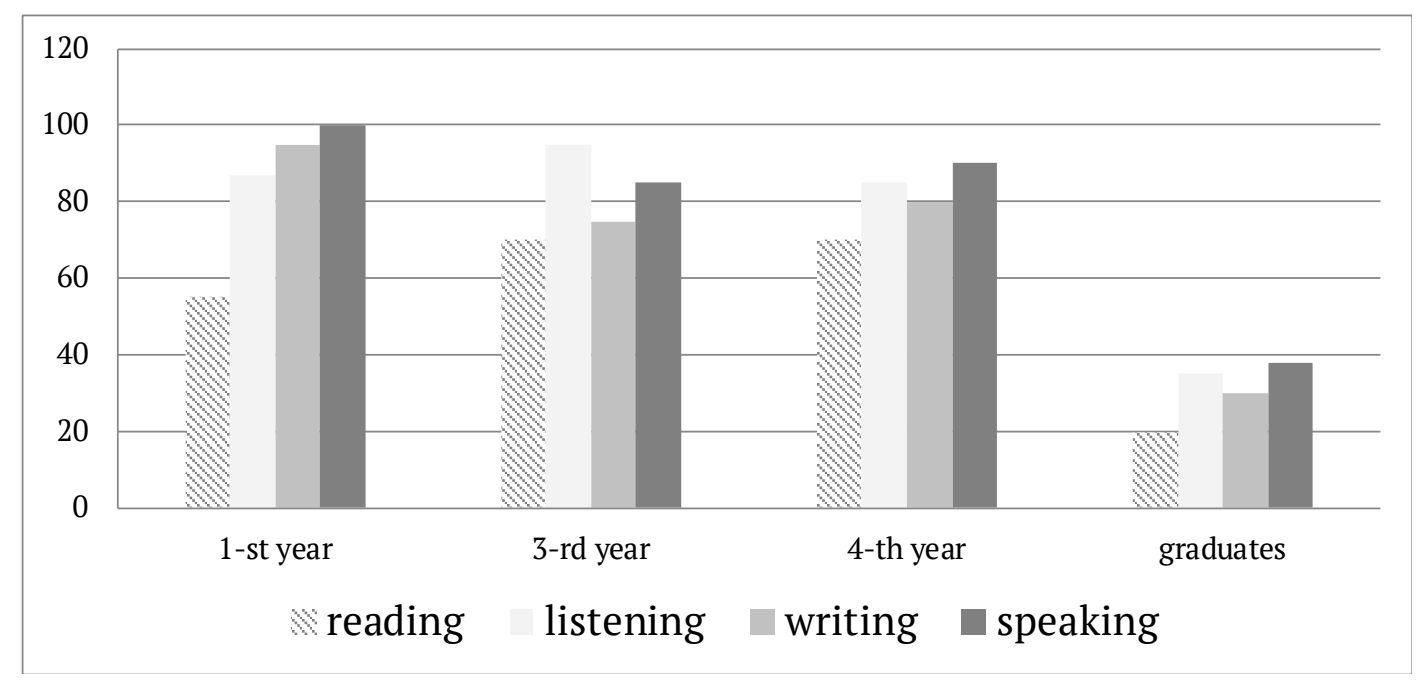

Figure 4. Foreign language skills in need of improvement. 
Table 2

Representation of the mean (X) and standard deviation (SD) for the levels of graduates' and students' perceived (\% of total) levels of language competence*

\begin{tabular}{|c|c|c|c|c|c|c|c|c|c|c|c|c|c|c|c|c|}
\hline \multirow{3}{*}{$\begin{array}{c}\text { CERF } \\
\text { levels }\end{array}$} & \multicolumn{4}{|c|}{ Reading } & \multicolumn{4}{|c|}{ Writing } & \multicolumn{4}{|c|}{ Listening } & \multicolumn{4}{|c|}{ Speaking } \\
\hline & \multicolumn{2}{|c|}{ I need } & \multicolumn{2}{|c|}{ I can } & \multicolumn{2}{|c|}{ I need } & \multicolumn{2}{|c|}{ I can } & \multicolumn{2}{|c|}{ I need } & \multicolumn{2}{|c|}{ I can } & \multicolumn{2}{|c|}{ I need } & \multicolumn{2}{|c|}{ I can } \\
\hline & $\bar{x}$ & SD & $\bar{x}$ & SD & $\bar{x}$ & SD & $\bar{x}$ & SD & $\bar{x}$ & SD & $\bar{x}$ & SD & $\bar{x}$ & SD & $\bar{x}$ & SD \\
\hline $\begin{array}{l}\text { first year } \\
\quad(n=30)\end{array}$ & 5.5 & 0.42 & 4.3 & 0.45 & 4.2 & 0.43 & 5.55 & 0.78 & 5.55 & 0.34 & 4.16 & 0.78 & 4.16 & 0.27 & 4.16 & 0.36 \\
\hline $\begin{array}{l}\text { third year } \\
\quad(\mathrm{n}=31)\end{array}$ & 5.71 & 0.69 & 4.88 & 1.03 & 5.80 & 0.52 & 5.80 & 0.52 & 5.70 & 0.76 & 5.70 & 0.76 & 5.84 & 0.47 & 4.38 & 1.13 \\
\hline $\begin{array}{l}\text { fourth year } \\
\qquad(\mathrm{n}=49)\end{array}$ & 5.86 & 0.46 & 4.66 & 0.75 & 5.85 & 0.42 & 5.85 & 0.42 & 5.68 & 0.64 & 5.70 & 0.63 & 5.85 & 0.41 & 4.72 & 0.95 \\
\hline $\begin{array}{l}\text { Graduates } \\
\quad(\mathrm{n}=35)\end{array}$ & 5.46 & 0.76 & 5.42 & 1.03 & 5.42 & 0.95 & 5.38 & 0.94 & 5.40 & 0.76 & 5.40 & 0.76 & 5.50 & 0.76 & 5.12 & 0.95 \\
\hline
\end{tabular}

also pointed at the need for further development of their writing skills, mostly at the advanced C2 level, beyond what they had mastered. The fourth-year students perceived their need for developing writing skills at the advanced level in an even more dramatic way than the graduates. They reported their needs as exceeding their perceptions of their current writing ability by fourfold.

Regarding listening skills, the results of the statistical analysis in Table 2 reveal a balance of needs and abilities for students, with the exception of the first year of study and the graduates. The major difference lies in the level of satisfaction: overall, the graduates were less satisfied with their listening skills than the students were.

The responses for speaking skills present a different picture. The descriptive data of the mean reveal an overall need for most groups to improve their speaking skills compared to what they could already do at that stage. The percentage breakdown (Appendix B) shows that this holds true for the C2 speaking skills: the graduates and the students were satisfied with their speaking ability being below the mastery level. One striking finding was that the first-year students were more confident about their speaking skills at levels below mastery levels than the third and fourth-year students. Interestingly, the fourth-year students were also the second-least confident about their ability to speak at the level of mastery.

In sum, our findings suggest that students set their goals at achieving $\mathrm{C} 1-\mathrm{C} 2$ levels in all four skills while being quite confident at lower levels. The respondents also agreed about speaking in the workplace demanding greatest mastery levels. The findings are in line with both the graduates' satisfaction and the reported difficulties regarding their ability to use the four language skills at their workplaces. This fact raises a question concerning the frequency of using the four language skills, of which speaking was not the most frequently cited activity. The question is whether the graduates do not speak as often because there are fewer opportunities for oral communication or because the graduates feel less confident in their ability.

\section{Comparative Statistical Analysis Across the Groups of Respondents}

A statistical analysis of the respondents' answers by groups revealed the magnitude of the convergence/ divergence of their views on the needs of foreign-language communication in a professional environment (see Table 3). The calculated value of $F(6.0311$ ) significantly exceeds 1 (one) at $p=0.0002$, which indicates more significant variations between the groups than within the groups. The $p$-value corresponding to the $F$-statistic of one-way ANOVA is lower than 0.05 , suggesting that the groups are significantly different in their views. The analysis may suggest that the grouping variable (year of studies) plays a role in shaping the students' views. Significant differences are traced between the graduates and the groups of students.

With regard to the average assessment of the perception of foreign language practice by graduates, the greatest deviation from the views of graduates was revealed among the first-year students. The views of the third-year students showed a lower coefficient of deviation from the views of graduates in the Tukey HSD and Bonferroni tests. In these tests, the only insignificant deviation was revealed in the views of the graduates and the fourthyear students. 
Table 3

Tukey HSD, Bonferroni and Holm results (only pairs relative to graduates simultaneously compared)

\begin{tabular}{|c|c|c|c|c|c|c|c|c|}
\hline \multirow{2}{*}{ Compared groups } & \multicolumn{2}{|c|}{ Tukey HSD } & \multirow{2}{*}{$\begin{array}{l}\text { Tukey HSD } \\
\text { inference }\end{array}$} & \multirow{2}{*}{$\begin{array}{l}\text { Bonferroni } \\
\text { and Holm } \\
\text { t-statistic }\end{array}$} & \multirow{2}{*}{$\begin{array}{l}\text { Bonferroni } \\
\text { p-value }\end{array}$} & \multirow{2}{*}{$\begin{array}{l}\text { Bonferroni } \\
\text { inference }\end{array}$} & \multirow{2}{*}{$\underset{\text { p-value }}{\text { Holm }}$} & \multirow{2}{*}{$\begin{array}{c}\text { Holm } \\
\text { inference }\end{array}$} \\
\hline & Q statistic & p-value & & & & & & \\
\hline $\begin{array}{l}\text { first-year students/ } \\
\text { graduates }\end{array}$ & 5.7963 & 0.0010053 & $* * p<0.01$ & 4.0986 & 0.0008755 & $* * p<0.01$ & 0.0007879 & $* * p<0.01$ \\
\hline $\begin{array}{l}\text { third-year students/ } \\
\text { graduates }\end{array}$ & 4.7088 & 0.0106250 & $* p<0.05$ & 3.3296 & 0.0123898 & ${ }^{*} p<0.05$ & 0.0099119 & $* * p<0.01$ \\
\hline $\begin{array}{l}\text { fourth-year } \\
\text { students/ graduates }\end{array}$ & 1.4246 & 0.8331633 & insignificant & 4.2908 & 0.0143593 & $* p<0.05$ & 0.0100515 & $* p<0.05$ \\
\hline
\end{tabular}

Note: (* significant differences *** more significant differences)

\section{Perceptions of the Learning Context by Students and Graduates}

In terms of the pedagogical organization (q-s 23, 26-28), the results show that the third-year students and graduates favored the pedagogical setup that presupposes groups by level of competence. There are two findings regarding the fourth-year students that appear worth noting. First, they prefer to do more teamwork than the other respondents. Second, they are not very supportive of guided autonomous learning (e.g. online). Students were more responsive than graduates to the questions on pedagogical setup, which may be explained by their current engagement in the educational process.

Considering the content of the studies, most of the students and graduates (86\%) responded that language teaching should be more oriented towards specific professional language. Generally, all of the participants (including students, graduates) believed that the ratios of specific $F L$ (economics/politics) teaching time to general $F L$ teaching time on the scale $20 / 80$ to $80 / 20$ are as follows: $60 / 40=28 \%$; $70 / 30=22 \% ; 50 / 50=20 \%$; $40 / 60=18 \%$; other ratios: $=12 \%$. Most of the third and fourth-year students $(74.2 \%$ and $87.8 \%$, respectively) were highly motivated to continue with their language learning to improve their language skills or to maintain their skill level, while less than a half of the graduates (31.4\%) did not continue language learning. More than half of the graduates (58\%) said that they were self-motivated to take further steps to improve linguistically, as was the case with Taillefer's (2007) findings. Interestingly, $12.9 \%$ of the third-year students and $17.1 \%$ of the graduates left the response slot blank, while everyone from the fourth-year sample group gave responses to this question.

\section{Discussion}

This study set out to examine the perceptions of language learning needs as shared by non-English major FL students and graduates. The findings suggest that in the course of studying the students may be generally getting more realistic in their expectations of how important foreign languages may be at their future workplace and in which contexts the use of foreign languages will prevail. However, the percentage of graduates reporting satisfaction with the level of their language training in school (q-n 26), though encouraging (54\%), is far from being the target result of the language program. The research findings may lead to some considerations for adjusting the learning process.

First, the perceptions of the students in the professional context for language use deviate from those of the graduates in terms of frequency and cultural environment. The students expected to communicate in the FL native speakers' environment more often than the graduates did. The deviations concerning the expectations for the context of using separate skills mostly concern speaking. The students expected to speak more often and have more active participation at meetings and make more presentations than the graduates. This fact is consistent with the study of Grosling and Ward (2002), who found that workplace presentations and meeting participation for the responding graduates of Monash University, Australia, were limited. Moreover, the students may be unaware of how much reading and writing are required in the workplace.

Second, the research findings may indicate the difference in weight that each of the four foreign language 
skills carries at the employment threshold and workplace. Although the majority of participants in all four groups ascribed considerable importance to all four skills, the graduates overwhelmingly cited reading as most frequently required for the work context, while writing and speaking were more valued at the employment stage compared to the students' expectations. The conclusion regarding the order of skill importance for the workplace may not ring true for all industries, as is the case with engineering graduates (Kassim \& Ali, 2010). Their analysis of the data collected from 65 engineers at 10 multinational chemical companies in Malaysia depicted an emphasis on oral workplace communication skills while networking for contacts and presenting new ideas as a means of professional advancement. Still, the recruitment stage requirements confirm reports from previous studies that found the impact of oral communication skills the most pronounced on recruitment compared to job success or promotion (Crosling \& Ward, 2002) or "essential" for both recruitment and promotion as compared to "daily tasks" (Kassim \& Ali, 2010, p. 176). Moreover, a number of findings are in concordance with the conclusions in Taillefer's (2007) research of the professional needs of economics graduates in France, which stated that language competence was not the decisive employment factor for a large proportion of graduates; still, all language skills were reported by graduates as highly important for further professional communication in the workplace.

Third, whatever the preferences of the participants may be in assessing their own levels of language competence, both the graduates and the students expressed a clear need for all four language skills to be developed at a level as high as $\mathrm{C} 2$, with an emphasis on mastery in speaking. In summary, speaking appears to be perceived as the most required but least developed skill for workplace use. Speaking skills were also regarded as insufficient at all stages of employment. The need to improve speaking is consistent with a number of other studies in the field (Marza, 2012; Kassim \& Ali, 2010; Li \& Lu, 2011; Stevens, 2017; Talib, 2018). The other three language skills in which the students were quite confident were viewed by the graduates as being in need of considerable improvement, up to the level of mastery. It should be noted that the differences discussed above, though noticeable, are still far from being drastic.

The results of the research may be important for the design of efficient curricula as well as defining vectors of possible further research. As already stated in Liu et al. (2011), first and foremost, informing instructors on the complexities of the students' needs and the challenges that the students may face in their future workplaces appear to be imperative. A systematic collection of students' needs and their analysis might help to design a "defensible curriculum" (Brown, 2016, p.102). To complement "subject area knowledge relationships with content-area specialists and specialized texts" (Starfield, 2016, p. 157), scheduling timely and regular workplace context updates from former graduates may allow for the timely adjustment of syllabi/curricula as well as instructors' personal approaches to teaching. Researchers themselves, as Brown (2016) notes, may have an obligation to disseminate the findings among those who may benefit from them.

Language-wise, one possible way to provide quality teaching at an advanced level with a limited number of class instructional hours appears to be the incorporation of training on different language skills with the most applicable context for their use. For example, listening difficulties reported by our respondents revealed the need to use authentic interviews revolving around essential subjects. Within such a framework, language activities for situations of heightened professional problematicity (Marina \& Rajprasit, 2016) involving situation-specific factors (Kankaanranta \& Louhiala-Salminen, 2010) for speaking and negotiation training, including phone conversations, appear logical and may also be offered. Reading may be enhanced by tasks for critical reading based on a selection of relevant professional texts. Efficient follow-up activities in this case could include those engaging students in writing to reflect specific workplace requirements. Moreover, the participants in the study preferred traditional forms of pedagogical organization over "new technologies," which mirrors Taillefer's (2007, p.11) research results. This fact may point to shared tendencies in culturally different learning contexts of French and Russian universities.

The decline of the deviation coefficient for the perceptions of foreign language practice by the students as their move from the first to the fourth year and then graduate raises a question about the factors that may be shaping students' views on their language needs throughout their university years. For instance, further research could look into the role of instructors and graduates in influencing students' perceptions of their need to learn foreign languages for professional use in general, and specifically in all four skills - reading, writing, speaking, and listening - across different communication settings. Graduates may communicate their views on their need to learn and use foreign languages through personal contacts with their student friends, which instructors rarely maintain. The fourth-year students may also adjust their perceptions about their future 
language learning needs through their recruitment and workplace experiences as they start looking for a paid job while studying. For instance, 50\% of students in Russian universities actively did this in the years of 20132014 (Roshchin \& Rudakov, 2014).

There are some limitations that must be taken into consideration. First, the research referred overwhelmingly to ESP and ESAP, rather than incorporating other languages into the framework of LSP. The authors are aware that such a focus may blur possible language-dependent variations in terms of the participants' needs perceptions, even though all of the research participants were involved in ESP along with LSP, thus sharing the ESP experience. Moreover, the discussion on the necessity of foreign language skills to address the actual needs of future professionals appeared in the field of English as a foreign language (EFL) and, since then, has spread widely through numerous research studies on teaching other languages. Still, conducting cross-FL analyses on the data may help to overcome limitations regarding conflation of ESP with LSP.

Second, despite adjusting the questionnaire regarding jobs, which was performed with the use of FL, the questions regarding the learning context also should have been adjusted because they failed to provide enough opportunities for the respondents to offer more alternatives to the suggested multiple choices. In hindsight, more open-ended questions may be advisable because some responses may have benefitted from being justified: the reason why guided autonomous learning was nearly unanimously downgraded by the students in response to question 27; the factors that contribute most to highly motivated former fourth-year students not continuing their language studies ( $\mathrm{q}-\mathrm{n}$ 23a) as graduates, and the actions taken by the graduates who did report taking action to improve their language skills as described by 'personal motivation' ( $q-n 23 b)$. Thus, more qualitative data are needed. Post-questionnaire structured interviews to support selected questions are being planned in coming research projects to add proper qualitative data.

\section{Conclusion}

This empirical study of needs analyses in the context of ESP/LSP in a Russian university has revealed potentially useful findings with the implications drawn for research, curriculums, and pedagogy. The analysis supports conclusions shared by a number of research papers in the field across different subject areas of FL application, with some information that may add new insights into not only the Russian educational context but also the international research area. One of the major implications of the study that may contribute to improving the learning process points at a divergence of students' expectations and working graduates' views on language needs in the workplace. The finding may stress the need for updating both students and instructors on the reallife FL requirements needed to become a part of an institutional routine.

Despite the limitations regarding the scope and the materials design, the current research may suggest several vectors to follow, such as expanding the research by number of participants, scope (including a cross-FL needs analysis on the data), stakeholders that may shape the perception of students (e.g., instructors, higher institution administration, employers), and/or geography. Whereas the findings of this study cannot be generalized to many contexts due to the limited scale and specificity of the context, the authors hope that the study can contribute to raising the awareness of university instructors regarding their students' perceptions of language learning needs and actual workplace demands, which would inform their instructional approaches and practices.

\section{Acknowledgement}

The authors would like to thank the Center for Institutional Research of National Research University Higher School of Economics for their invaluable help in collecting data for the research. 


\section{References}

Basturkmen, H. L., \& Wette, R. (2016). English for academic purposes. In G. Hall (Ed.), The Routledge Handbook of English Language Teaching (pp. 164-176). Abingdon, UK: Routledge.

Belcher, D. (2006). Trends in teaching English for specific purposes. Annual Review of Applied Linguistics, 24, 165-186. doi: 10.1017/S026719050400008X

Belcher, D. (2009). What ESP is and can be. In D. Belcher (Ed.), English for specific purposes in theory and practice (pp. 1-20). Ann Arbor, MI: University of Michigan Press.

Brown, D. (2001). The elements of language curriculum: A systematic approach to program development. Oxford, UK: Pergamon Press.

Brown, D. (2016). Introducing needs analysis and English for Specific Purposes. London, UK: Routledge.

Bucar, C. S., Ruy, H., Skof, N. M., \& Sangawa, K. H. (2014). The CEFR and teaching Japanese as a foreign language. Linguistica, 54(1), 455-469. doi: https://doi.org/10.4312/linguistica.54.1.455-469

Canagarajah, S. (2002). Multilingual writers and the academic community: Towards a critical relationship. Journal of English for Academic Purposes, 1, 29-44. Retrieved from http://proxylibrary.hse.ru:2155/10.1016/ S1475-1585(02)00007-3

Crosling, G., \& Ward, I. (2002). Oral communication: The workplace needs and uses of business graduate employees. English for Specific Purposes, 21, 41-57.

Douglas, D. (2000). Assessing language for specific purposes. Cambridge, UK: Cambridge University Press.

Dudley-Evans, T., \& St. John, M. (1998). Developments in ESP: A multi-disciplinary approach. Cambridge, UK: Cambridge University Press.

Evans, S., \& Morrison, B. (2011). Meeting the challenges of English-medium higher education: The first-year experience in Hong Kong. English for Specific Purposes, 30(3), 198-208. doi.org/10.1016/j.esp.2011.01.001

Garcia, P. (2002). An ESP program for entry-level manufacturing workers. In T. Orr (Ed.), English for Specific Purposes (pp. 161-174). Alexandria, VA: TESOL.

Howard, R., \& Brown, G. (1997). Five questions for LSP teacher training. In R. Howard \& G. Brown (Eds.), Teacher Education for languages for Specific Purposes (pp. 57-66). Philadelphia, PA: Multilingual Matters Ltd.

Hutchinson, T., \& Waters, A. (1987). English for specific purposes: A learning-centered approach. Cambridge, UK: Cambridge University Press.

Hutchinson, T., \& Waters, A. (2002). English for specific purposes. Shanghai, PRC: Shanghai Foreign Language Press.

Hyland, K., \& Hamp-Lyons, L. (2002). EAP: Issues and directions. Journal of English for Academic Purposes, 1(1), $1-12$.

Kankaanranta, A., \& Louhiala-Salminen, L. (2010). “English? - Oh, it’s just work!”: A study of BELF users' perceptions. English for Specific Purposes, 29(3), 204-209. doi: 10.1016/j.esp.2009.06.004

Kassim, H., \& Ali, F. (2010). English communicative events and skills needed at the workplace: Feedback from the industry. English for Specific Purposes, 29, 168-182. doi:10.1016/j.esp.2009.10.002

Kavaliauskien, G., \& Uzpaliene, D. (2003). Ongoing needs analysis as a factor to successful language learning. Journal of Language and Learning, 1(1), 35-50.

Kazakova, O. P. (2011). Professionalno-orientirovannoe obuchenie inostrannym yazykam [Profession-oriented teaching of foreign languages]. News of South Federal University. Pedagogical sciences, 6, 137-142. Retrieved from https://idm.dvfu.ru/uploads/firstatiaekaterinburg2014.pdf

Kazar, S. G., \& Mede, E. (2015). The perceptions of ESP students' target needs: A case study. Procedia - Social and Behavioral Sciences, 191, 2526-2530. doi:10.1016/j.sbspro.2015.04.574

Kirkgöz, Y., \& Dikilitaş, K. (Eds.). (2018). Key Issues in English for Specific Purposes in Higher Education (Vol. 11). Cham, Switzerland: Springer International Publishing.

Komarova, A. I., \& Oks, I. Y. (2016). Obucheniye ESP dlya spetsialnosti "tourism": struktura kursa, soderzhaniye I stil' uchebnogo materyala [Teaching English for tourism: the course structure, content and stylistic features of the text]. The Bulletin of Moscow University. Series 19. Linguistics and Cross-Cultural Communication, 3, 104118.

Lafford, B. A. (2012). Languages for Specific Purposes in the United States in a global context: Commentary on Grosse and Voght (1991) Revisited. Modern Language Journal, 96(1), 1-27. doi.org/10.1111/j.15404781.2012.01294.x

Lear, D. (2012). Languages for Specific Purposes Curriculum Creation and Implementation in Service to the U.S. Community. Modern Language Journal, 96(1), 158-172. doi.org/10.1111/j.1540-4781.2012.01302.x 
Li, P., \& Lu, Z. (2011). Learners' needs analysis of a new optional college English course -Interpreting for NonEnglish majors. Theory and Practice in Language Studies, 1(9), 1091-1102. doi:10.4304/tols.1.9.

Liu, J.-Y., Chang Y.-J., Yang, F.-Y., \& Sun, Y.-C. (2011). Is what I need what I want? Reconceptualising college students' needs in English courses for general and specific/academic purposes. Journal of English for Academic Purposes, 10, 271-280. doi:10.1016/j.jeap.2011.09.002

Long, M. K., \& Uscinski, I. (2012). Evolution of Languages for Specific Purposes programs in the United States: 1990-2011. Modern Language Journal, 96(1), 173-189. doi.org/10.1111/j.1540-4781.2012.01303.x

Louhiala-Salminen, L. (1996). The business communication classroom vs reality: What should we teach today? English for Specific Purposes, 15(1), 37-51. doi.org/10.1016/0889-4906(95)00024-0

Mackey, A., \& Gass, S. M. (2005). Second language research: Methodology and design. New Jersey, NJ: Lawrence Erlbaum Associates.

Marina, O., \& Rajprast, K. (2016). The role of personal factors in 'communication mobility' development of Thai and Russian professionals in BELF context. 3L: Language, Linguistics, Literature, 2(22), 1-21. Retrieved from http://ejournals.ukm.my/31/article/view/12454/4384

Nunan, D., \& Lamb, C. (1996). The self-directed teacher: Managing the learning process. Cambridge, UK: Cambridge University Press.

Nur, E. M. S., \& Darus, S. (2011). Workplace writing in English: Insights from Malaysian bank managers. GEMA Online ${ }^{\mathrm{TM}}$ Journal of Language Studies, 11(3), 219-233.

Orlyanskaya, T. G. (2012). Programma kursa LSP dlya studentov IV kurse otdeleniya lingvistiki I mezhkulturnoi kommunikatsii [The Syllabus of the LSP Course for Fourth-Year Students of the Department Linguistics and Intercultural Communication]. The Bulletin of Moscow University. Series 19. Linguistics and Cross-Cultural Communication, 4, 130-135.

Roshchin, S., \& Rudakov, V. (2014). Combining work and study by Russian higher education institution students. Educational Studies, 2, 152-179. doi: 10.17323/1814-9545-2014-2-152-179

Sarsenbayeva, A. S., \& Kulakhmetova, M. S. (2015). Angliyskiy dlya spetsyalnych tseley: neobhodimost' otsenky [English for specific purposes: Needs assessment]. Bulletin of Kemerovo State University, 1(4), 163-166.

Serafini, E. J., Lake, J. B., \& Long, M. H. (2015). Needs analysis for specialized learner populations: Essential methodological improvements. English for Specific Purposes, 40, 11-26. doi:10.1016/i.esp.2015.05.002

Shooshtari, Z. G., Haghighi, S. B., \& Bates, R. (2018). The catalysts and barriers of learning transfer in ESAP writing programs: Assessing learners' perceptions via the LTSI. Asian ESP Journal, 14(1), 193-219. Retrieved from https://www.elejournals.com/asian-esp-journal/

Soliman, R. (2017). The implementation of the Common European Framework of Reference for the teaching and learning of Arabic as a second Language in Higher Education. In K. M. Wahba, L. England \& Z. A. Taha (Eds.), Handbook for Arabic Language Teaching Professionals in the 2first Century (Vol. II, pp.118-138). New York, NY: Routledge.

Solovova, E. N. (2009). Angliyskiy dlya spetsyalnych tseley: Chemu uchit', kogda nachinat', kak otsenivat'? [English for specific purposes: What to teach, when to begin, how to correct?]. In English for Nonphilologists. Problems of ESP (pp. 5-13). Voronezh, Russia: Istoki.

Spence, P., \& Liu, G. (2013). Engineering English and the high-tech industry: A case study of an English needs analysis of process integration engineers at a semiconductor manufacturing company in Taiwan. English for Specific Purposes, 32(2), 59-130.

Stevens, S. G. (2017). "Step Out of the Cycle": Needs, challenges, and successes of international undergraduates at a U.S. University. English for Specific Purposes, 46, 15-28. doi: 10.1016/j.esp.2016.11.003

Starfield, S. (2016). English for specific purposes. In G. Hall (Ed.), Routledge handbook of English language teaching (pp. 150-163). London, UK: Routledge.

Taillefer, G. F. (2006). The professional language needs of economics graduates: Assessment and perspectives in the French context. English for Specific Purposes, 26(2), 135-155. doi:10.1016/j.esp.2006.06.003.

Talib, R. (2018). ESP needs analysis: A case study of communication science students, Faculty of Social Science, State University of Gorontalo. Asian EFL Journal, 20(1), 1738-1460. Retrieved from https://www.elejournals. com/asian-esp-journal/

Tan H. K., Teoh M. L., \& Tan, S. K. (2016). Beyond 'greeting' and 'thanking': Politeness in job Interviews. 3L: The Southeast Asian Journal of English Language Studies, 22(3), 171-184. doi: http://doi. org/10.17576/3L-2016-2203-12

Teng, Y. (2017). Hanyu Shuiping Kaoshi (HSK): Past, present, and future. In D. Zhang \& C.-H. Lin (Eds.), Chinese as a Second Language Assessment, Chinese Language Learning Sciences (pp. 3-18). Singapore, the Republic of Singapore: Springer Nature Singapore Pte Ltd. 
Tudor, I. (1997). LSP or language education? In R. Howard \& G. Brown (Eds.), Teacher education for LSP (pp. 90-102). Clarendon, UK: Multilingual Matters.

Varghese, R. (2012). An integrated teaching model to develop English proficiency of ESL management students. 3L: The Southeast Asian Journal of English Language Studies, 22(3), 171-184.

Yalden, J. (2000). Principles of curriculum design for language teaching. Beijing, PRC: Cambridge University Press.

Zohreh, R. E. (2010). Teachers' voice vs. students' voice: A needs analysis approach to English for Academic Purposes (EAP) in Iran. English Language Teaching, 3(1), 3-11. doi:http://dx.doi.org/10.5539/elt.v3n1p3 


\section{APPENDIX A}

\section{Questionnaire for Graduates of the School of World Economics and International Affairs (NRU HSE)}

Please answer the questions below. Your cooperation is INVALUABLE for the research aiming to improving foreign language teaching in our school.

Any extra comments are most welcome!

\section{INTRODUCTION}

1. Year of graduation:

before 2008 $\square \quad 2008 \square \quad 2009 \square \quad 2010 \square \quad 2011 \square \quad 2012 \square$

2. Specialization:

3. Did you continue your studies after graduation from the university?

$$
\text { Yes } \square \quad \text { No } \square
$$

4. Sex:

$$
\mathrm{F} \square \quad \mathrm{M} \square
$$

5. Age:

$$
26 \square \quad 27 \square \quad 28 \square \quad 29 \square \quad 30 \square \quad \text { other } \square
$$

6. How would you define your occupational field?

7. Your current job position can be described as: manager $\square \quad$ administrator $\square$ specialist $\square$ other $\square$

8. Mother tongue(s): Russian $\square \quad$ Other $\square$

9. On which foreign language did you concentrate at the university?
English $\square$
German $\square$
Spanish $\square$
French $\square$
Chinese $\square$
other $\square$

10. Do you use one or more foreign languages professionally?

If yes, which one(s)? Please list them in decreasing order.

1.

2.

3.

II. YOUR NEEDS (in the function of the foreign language indicated in question 10. Please tick all that are applicable):

\section{IN GENERAL..}

11. In what context do you currently use your main foreign language?

mostly formal situations (meetings, presentations)

mostly informal situations (social, everyday communication...)

direct contact (including telephone...)

virtual contact (e-mail...)

12. Where do you use your main foreign language?

in Russia 
in the native countries of this language (e.g., Japanese in Japan)

in the non-native countries of this language

13. With whom do you use your foreign language?

native speakers

non-native speakers

14. How often do you use these different competences in your foreign language?

Very often Fairly often Sometimes Rarely Never

$\begin{array}{ll}\text { Understanding: } & \text { Reading } \\ & \text { Listening } \\ \text { Communicating: } & \text { Writing } \\ & \text { Speaking }\end{array}$

15. Do you have difficulties using these different competences in your foreign language?

$\begin{array}{llccccc} & & \text { Very often } & \text { Fairly often } & \text { Sometimes } & \text { Rarely } & \text { Never } \\ \text { Understanding: } & \text { Reading } & \square & \square & \square & \square & \square \\ & \text { Listening } & \square & \square & \square & \square & \square \\ \text { Communicating: } & \text { Writing } & \square & \square & \square & \square & \square \\ & \text { Speaking } & \square & \square & \square & \square & \square\end{array}$

16. How important, in your mind, is the professional use of these different competences in foreign language? Important Somewhat important Not very important
Understanding: Reading
Communicating: Writing
Speaking

17. For what activities do you use your main foreign language in your job? Circle the appropriate letter. A-often; B-sometimes; C-seldom; D-never

Reading

1. Manuals

2. Instructions

3. Emails

4. Contracts

5. Product specifications

6. Price lists

7. Specialist literature

8. Legal documents

Other.

Speaking

1. Speaking to foreign visitors

2. Speaking to foreign colleagues

3. Speaking on the phone
Writing

$\begin{array}{lll}\text { A B C D } & \text { 1. Business letters } & \text { A B C D } \\ \text { A B C D } & \text { 2. Emails } & \text { A B C D } \\ \text { A B C D } & \text { 3. Memorandums } & \text { A B C D } \\ \text { A B C D } & \text { 4. Reports } & \text { A B C D } \\ \text { A B C D } & \text { 5. Articles } & \text { A B C D } \\ \text { A B C D } & \text { 6. Summaries of articles } & \text { A B C D } \\ \text { A B C D } & \text { 7. Notes } & \text { A B C D } \\ \text { A B C D } & \text { 8. Translations into foreign language } & \text { A B C D } \\ \text { A B C D } & \text { 9. Translations into native language } & \text { A B C D } \\ & \text { 10. Legal papers } & \text { A B C D } \\ \text { A B C D } & \text { 11. Price lists } & \text { A B C D } \\ \text { A B C D } & \text { 12. Product specifications } & \text { A B C D } \\ \text { A B C D } & \text { Other........................................ } & \text { A B C D }\end{array}$


4. Taking part in meetings

5. Taking part in conferences

6. Chairing meetings

7. Giving presentations

8. Giving instructions

9. Asking questions

Other.
A B C D Listening

A B C D 1. Instructions A B C D

ABCD 2. Lectures ABCD

$A B C D$ 3. Presentations A B C D

A B C D 4. Reports A B C D

$\mathrm{ABC} D \quad$ Other .................................. A B C D

\section{MORE PRECISELY about language...}

Levels of competence in foreign languages, as described by the Council of Europe and given below, are ranked from weakest (---) to strongest (+++).

In column A, please tick the level which, according to you, is necessary to perform efficiently at work. In column $\mathrm{B}$, please tick the level corresponding to your present competence.

Please tick only one level of competence in each column.

18. UNDERSTANDING: Reading

LEVELS OF COMPETENCE (from weakest to strongest)

--- $\quad$ read simple words and phrases in everyday life

-- $\quad$ read short and simple texts for the gist or for specific information

- $\quad$ Slowly read texts written in everyday language or related to my studies

$+\quad$ read articles or reports expressing a particular point of view, assuming that there is adequate time

$+\quad$ read longer, complex, specialized texts and appreciate differences in style in a reasonable time frame

+++ read any type of text easily, even abstract or complex documents, appreciating subtle distinctions of style and implicit as well as explicit meaning

\section{UNDERSTANDING: Listening}

LEVELS OF COMPETENCE (from weakest to strongest)

--- understand words and basic or familiar expressions in a limited context

-- understand expressions and common vocabulary related to my immediate environment

- $\quad$ understand key points in clear and standard speech when people speak slowly on familiar topics

$+\quad$ understand longer discussions and follow complex lines of argument on familiar topics; understand most news programs in the standard dialect

++ understand extended speech, even when it is not clearly structured, and TV programs with relative ease

+++ understand any type of spoken language, whether live or broadcast, as long as I have time to become familiar with a particular accent
A B

Is necessary I can

$\begin{array}{ll}\square & \square \\ \square & \square \\ \square & \square \\ \square & \square \\ \square & \square \\ \square & \square\end{array}$

A

B

Is necessary I can

$\begin{array}{ll}\square & \square \\ \square & \square \\ \square & \square \\ \square & \square \\ \square & \square \\ \square & \square\end{array}$


20. COMMUNICATING: Writing

LEVELS OF COMPETENCE (from weakest to strongest)

--- $\quad$ write short, specific pieces of information

-- $\quad$ write short, simple notes and messages

- $\quad$ write coherent texts or notes on familiar subjects

$+\quad$ write clear and detailed texts, reports and essays on topics in my field

$+\quad$ write clear, well-structured texts and develop my point of view on complex subjects

+++ write clear, smooth, stylistically appropriate texts; write summaries or critical reviews

\section{COMMUNICATING: Listening}

LEVELS OF COMPETENCE (from weakest to strongest)

--- use basic expressions and phrases and ask simple questions on familiar subjects, as long as my interlocutor is willing to help me understand and

-- $\quad$ express myself

- $\quad$ respond with familiar topics and describe my university course in simple terms; carry on a very limited conversation

+ generally explain my opinions or projects; spontaneously participate in conversations on familiar topics

++ express myself clearly and in detail, actively participate in conversations on topics related to my interests; spontaneously communicate with a native speaker

+++ describe complex subjects clearly and in an appropriate manner; express myself spontaneously, clearly and easily in professional or social contexts

describe or argue about complex subjects clearly and easily in an appropriate manner; express myself in any situation in standard, idiomatic language with appropriate nuances; correct myself in a natural way that draws little notice

22. Presently, in your work, is it necessary for you to improve your....

$$
\begin{aligned}
& \text { - reading comprehension? } \\
& \text { - listening comprehension? } \\
& \text { - writing skills? } \\
& \text { - speaking skills? }
\end{aligned}
$$

23. a. Are you taking action to improve your language skills or to maintain your level? b. If yes, is it ...

$$
\begin{aligned}
& \text { - out of personal motivation? } \\
& \text { - out of professional obligation? }
\end{aligned}
$$
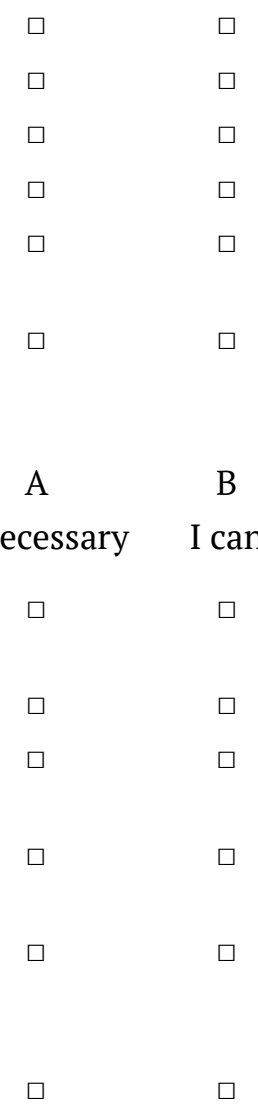

$\begin{array}{ll}\text { Yes } \square & \text { No } \square \\ \text { Yes } \square & \text { No } \square \\ \text { Yes } \square & \text { No } \square \\ \text { Yes } \square & \text { No } \square \\ \text { Yes } \square & \text { No } \square \\ \text { Yes } \square & \text { No } \square \\ \text { Yes } \square & \text { No } \square\end{array}$




\section{WHEN YOU OBTAINED YOUR FIRST JOB...}

24. Did you feel that your foreign language skills were sufficiently developed upon entering the job market in...:

- reading comprehension?

- listening comprehension?

- writing skills?

- speaking skills?

$\begin{array}{cc}\text { Yes } \square & \text { No } \square \\ \text { Yes } \square & \text { No } \square \\ \text { Yes } \square & \text { No } \square \\ \text { Yes } \square & \text { No } \square\end{array}$

25. Were you hired especially due to your level in foreign language....

- reading comprehension?

Yes $\square \quad$ No $\square$

- listening comprehension?

Yes $\square \quad$ No $\square$

- writing skills?

Yes $\square \quad$ No $\square$

- speaking skills?

Yes $\square \quad$ No $\square$

IV. WHAT WOULD YOU SUGGEST FOR FOREIGN LANGUAGE TEACHING AND LEARNING AT THE UNIVERSITY (In light of your answers to the preceding questions)?

26. Do you feel that the foreign language training you received at the School of World Economy and International Affairs at the NRU HSE was useful?

Concerning the pedagogical organization of language teaching...

27. do you feel that language teaching should be organized in the form of (you may tick several answers)...

- regular classes/seminars?

Yes $\square \quad$ No $\square$

- guided autonomous learning (possibly online)?

Yes $\square \quad$ No $\square$

- teamwork (projects)?

Yes $\square \quad$ No $\square$

- groups by level of competence?

Yes $\square \quad$ No $\square$

- other:

28. a. Should language teaching be oriented...

$\begin{array}{lll}\text { - more towards specific economic and professional language? } & \text { Yes } \square & \text { No } \square \\ \text { - more towards general language? } & \text { Yes } \square & \text { No } \square\end{array}$

б. What ratio of economic and professional language to general language would you prefer?
$20 / 80 \square$
$30 / 70 \square$
$40 / 60$ 口
$50 / 50 \square$
$60 / 40 \square$
$70 / 30 \square$
$80 / 20 \square$ 
IRINA YAKUSHEVA, OLGA MARINA, OKSANA DEMCHENKOVA

APPENDIX B

Participants' perceived (\% of total) levels of main foreign language competence.*

\begin{tabular}{|c|c|c|c|c|c|c|c|c|c|}
\hline & \multirow{2}{*}{$\begin{array}{l}\text { CERF } \\
\text { levels }\end{array}$} & \multicolumn{2}{|c|}{ Reading } & \multicolumn{2}{|c|}{ Writing } & \multicolumn{2}{|c|}{ Listening } & \multicolumn{2}{|c|}{ Speaking } \\
\hline & & $\begin{array}{c}\text { I need } \\
\text { (\%) }\end{array}$ & $\begin{array}{c}\text { I can } \\
\text { (\%) }\end{array}$ & $\begin{array}{c}\text { I need } \\
\text { (\%) }\end{array}$ & $\begin{array}{c}\text { I can } \\
\text { (\%) }\end{array}$ & $\begin{array}{c}\text { I need } \\
\text { (\%) }\end{array}$ & $\begin{array}{c}\text { I can } \\
\text { (\%) }\end{array}$ & $\begin{array}{c}\text { I need } \\
\text { (\%) }\end{array}$ & $\begin{array}{l}\text { I can } \\
\text { (\%) }\end{array}$ \\
\hline & & \multicolumn{8}{|c|}{ first year $(n=30)$} \\
\hline$C 2$ & & 100 & - & 100 & - & 100 & - & 100 & - \\
\hline C1 & & 40 & 47 & 53 & 27 & 47 & 53 & 66 & 14 \\
\hline B2 & & 33 & 66 & 27 & 60 & 33 & 33 & 47 & 40 \\
\hline B1 & & 14 & 93 & 20 & 78 & 7 & 54 & 20 & 80 \\
\hline$A 2$ & & 14 & 93 & 14 & 86 & 14 & 86 & 14 & 86 \\
\hline \multirow[t]{2}{*}{$A 1$} & & 14 & 100 & 14 & 86 & 14 & 86 & 14 & 86 \\
\hline & & \multicolumn{8}{|c|}{ third year $(n=31)$} \\
\hline$C 2$ & & 83 & 35 & 85 & 44 & 83 & 42 & 88 & 27 \\
\hline$C 1$ & & 4 & 31 & 10 & 36 & 9 & 8 & 8 & 8 \\
\hline$B 2$ & & 13 & 23 & 5 & 12 & 4 & 23 & 4 & 42 \\
\hline$B 1$ & & - & 12 & - & 8 & 4 & 4 & - & 23 \\
\hline \multirow[t]{2}{*}{ A2 } & & - & - & - & - & - & - & - & - \\
\hline & & \multicolumn{8}{|c|}{ fourth year $(n=49)$} \\
\hline$C 2$ & & 90 & 12 & 87 & 22 & 77 & 30 & 88 & 8 \\
\hline$C 1$ & & 6 & 46 & 11 & 40 & 14 & 20 & 10 & 28 \\
\hline$B 2$ & & 4 & 38 & 2 & 26 & 9 & 26 & 2 & 44 \\
\hline$B 1$ & & - & 4 & - & 12 & - & 22 & - & 16 \\
\hline A2 & & - & - & - & - & - & - & - & 4 \\
\hline \multirow[t]{2}{*}{ A1 } & & - & - & - & - & - & 2 & - & - \\
\hline & & \multicolumn{8}{|c|}{ Graduates $(\mathrm{n}=35)$} \\
\hline$C 2$ & & 62 & 65 & 62 & 87 & 56 & 44 & 62 & 38 \\
\hline$C 1$ & & 23 & 23 & 23 & 11 & 28 & 32 & 31 & 46 \\
\hline$B 2$ & & 15 & 4 & 8 & 2 & 16 & 16 & 4 & 12 \\
\hline$B 1$ & & - & 4 & 8 & - & - & 8 & 4 & 4 \\
\hline$A 2$ & & - & 4 & - & - & - & - & - & - \\
\hline
\end{tabular}

Note: * Stated in terms of 'I need' vs. 'I can', according to CEFR; ( $p<0.0001)$ 